MT-DP - 2015/13

\title{
Mortgages denominated in domestic and foreign currencies: simple models
}

\author{
JÚLIA KIRÁLY - ANDRÁS SIMONOVITS
}


Discussion papers

MT-DP - 2015/13

Institute of Economics, Centre for Economic and Regional Studies, Hungarian Academy of Sciences

KTI/IE Discussion Papers are circulated to promote discussion and provoque comments. Any references to discussion papers should clearly state that the paper is preliminary. Materials published in this series may subject to further publication.

Mortgages denominated in domestic and foreign currencies: simple models

Authors:

Júlia Király

Head of Department

Teaching and Research Centre

Department of Economics and Finance

International Business School, Budapest

e-mail: jkiraly@ibs-b.hu

András Simonovits

research advisor

Institute of Economics - Centre for Economic and Regional Studies

Hungarian Academy of Sciences

also Mathematical Institute of Budapest University of Technology

and Department of Economics of CEU

e-mail: simonovits. andras@krtk.mta.hu

February 2015

ISBN $978-615-5447-72-3$

ISSN $1785377 X$ 


\title{
Mortgages denominated in domestic and foreign currencies: simple models
}

\author{
Júlia Király - András Simonovits
}

\begin{abstract}
After the short temporary popularity of FX denominated loans, during the Great Financial and Economic Recession (2007-2013), the burden of these loans has become unaffordable for a lot of borrowers. We have designed a family of simple models to compare the cash flows of installments and the paths of outstanding debts denominated in domestic and foreign currencies, respectively. Having these models, we are able to draw several conclusions relevant to the recent debates about the foreign currency denominated loans. Our study demonstrates the key role played by the uncovered interest rate parity in comparisons. Moreover, we give a closed-form solution for the trade-off between the depreciation and the unilateral interest rate increases by the banks. In a simple model, we determine the optimal size for domestic and foreign currency denominated loans, respectively.
\end{abstract}

Keywords: mortgage, currency denominated loan, credit crisis, payback models with annuity

JEL classification: C63, D14, G21 


\title{
Jelzáloghitel-törlesztés forintban és devizában: egyszerű modellek
}

\author{
Király Júlia - Simonovits András
}

\section{Összefoglaló}

A devizaalapú jelzáloghitelek néhány éves népszerüség után, a nemzetközi válság kitörését követően jelentős, nem egyszer elviselhetetlen terhet jelentettek a hitelfelvevőknek. Olyan minimális modellcsaládot állítunk fel, amely alkalmas a forint- és a devizaalapú jelzáloghitelek törlesztési- és adósságpályáinak összehasonlítására és számos - a mai devizaalapú hitelek körüli viták szempontjából - fontos tanulság levonására. Tanulmányunk megmutatja, hogy miért referencia a fedezetlen kamatparitásnak megfelelő leértékelődés melletti adósságpálya. Zárt képletben adjuk meg, hogy a devizaadós számára mi az átváltás az árfolyamromlás és az egyoldalú banki kamatemelés okozta hatás között. Egy egyszerü modell keretében kitérünk a forint-, illetve devizaalapú hitel optimális nagyságának meghatározására.

Tárgyszavak: jelzáloghitelezés, devizaalapú hitelek, hitelválság, annuitásos törlesztő modellek

JEL kód: C63, D14, G21 


\title{
Mortgages denominated in domestic and foreign currencies: Simple models
}

\author{
Júlia Király and András Simonovits
}

February 11, 2015

1) International Business School, Budapest, Záhony u 7, Hungary, 1031 e-mail: jkiraly@ibs-b.hu.

and

2) Institute of Economics, CERS, Hungarian Academy of Sciences also Mathematical Institute of Budapest University of Technology, and Department of Economics of CEU

Budapest, Budaörsi út 45, Hungary, 1112

e-mail: simonovits.andras@krtk.mta.hu,

\begin{abstract}
After the short temporary popularity of foreign currency denominated (FXD) loans, during the Great Financial and Economic Recession (20072013), the burden of these loans has become unaffordable for a lot of borrowers in East Central Europe. We have designed a family of simple models to compare the cash flows of installments and the paths of outstanding debts denominated in domestic and foreign currencies, respectively. Having these models, we are able to draw several conclusions relevant to the recent debates about the FXD loans. Our study demonstrates the key role played by the uncovered interest rate parity in the comparisons. Moreover, we give a closed-form solution for the trade-off between the depreciation and the unilateral FX interest rate increases by the banks. Adding a lifetime utility function to our simple model, we determine the optimal size for domestic and foreign currency denominated loans, respectively.
\end{abstract}

Keywords: mortgage, currency denominated loan, credit crisis, payback models with annuity

JEL: C63, D14, G21 


\section{Introduction}

In the 2000s, loans denominated in foreign currencies (for short, FXD loans) have spread in a number of East- and Central European countries, namely in the Baltic Republics, Croatia, Hungary, Poland, Romania (Figure 1 and see e.g. Zettelmeyer et al. (2010) and Király and Banai (2014)). In most of these countries, inflation rates had been high and volatile, exchange rates had been stable or even appreciating, the low Euro and the even lower Swiss franc interest rates and the expected close date of joining the Euro have made the FXD loans attractive (Brown and de Haas (2012), Fidrmuc et al. (2013)). All these circumstances contributed to the fact that by 2008 in most of these countries, the FXD loans had summed up to 50-80\% of the total household loans.

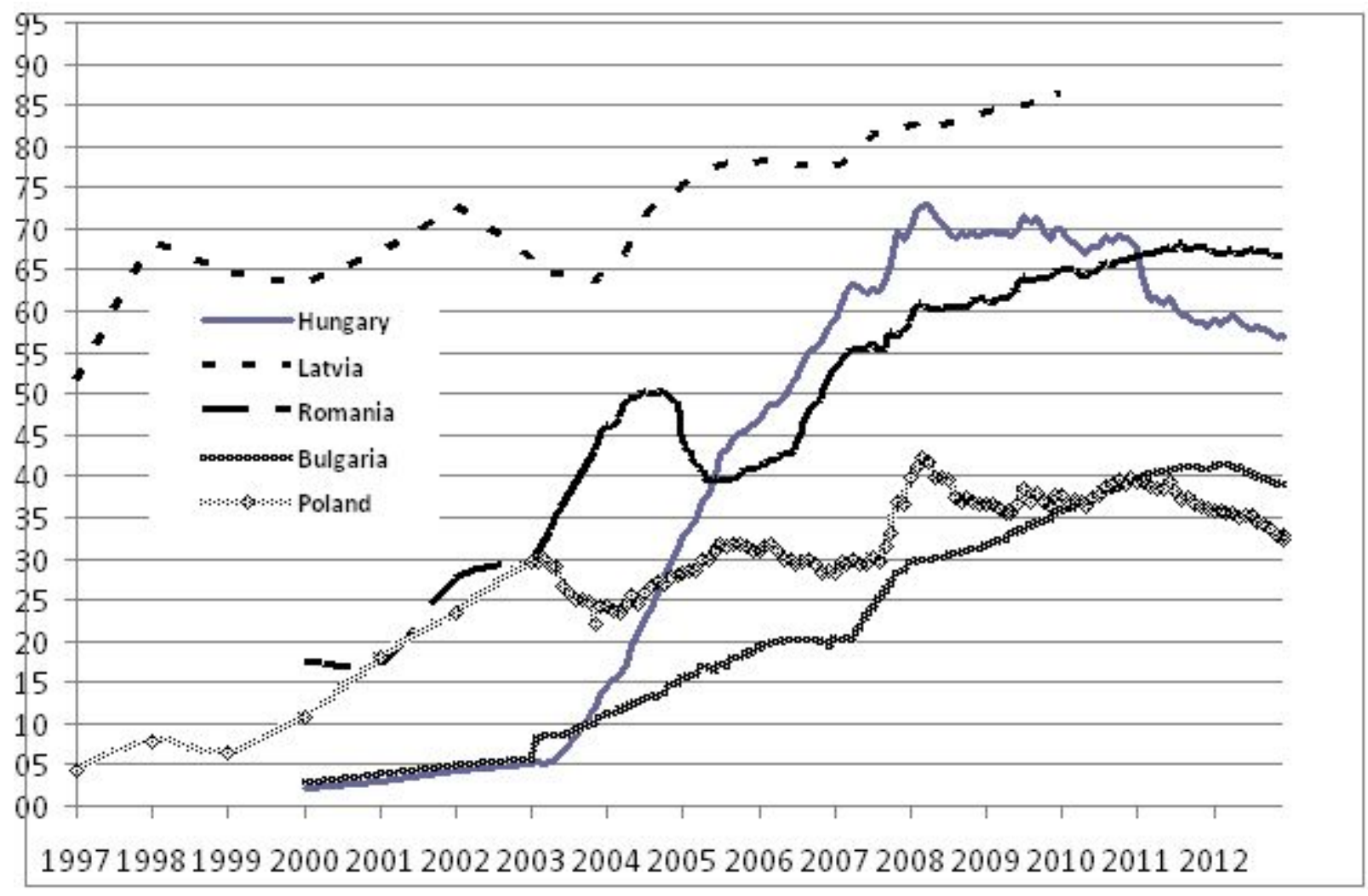

Figure 1: The share of FDX loans in several ECE countries. Source: the webpage of the National Banks of the foregoing countries.

The international financial crises started in 2007, which quickly widened into an economic crisis. At the Fall of 2008, the waves generated by default of the Lehman Brothers also reached the over indebted ECE countries and as a result, their 
currencies substantially weakened. For example, the Hungarian forint depreciated by $25 \%$ with respect to the Swiss franc (FX), and after weak appreciation, at the crisis of the euro-zone in 2011 also depreciated another 25\%. ${ }^{1}$ In the Baltic Republics, which were most indebted in FX, due to the cautiously preserved currency board, the exchange rates remained fixed and the exceptionally strict austerity was achieved through internal devaluation: the nominal values of public sector wages and pensions were significantly reduced. ${ }^{2}$ In other related countries (e.g. Poland), the unfavorable impact of currency depreciation was significantly counterbalanced by the drop in the foreign interest rate, either Euro or Swiss franc (Király and Banai, 2014).

In Hungary, however, - almost uniquely in Europe - the interest rates in the retail market were not fixed or floating rates, but so-called variable rates, which could be discretionally modified by the lenders. Due to the significantly rising CDS of Hungary, the additional cost of worsening portfolios and the rising fiscal burdens, the banks in Hungary did not follow the diminishing FX interest rates, rather they increased them several times (Pitz and Schepp (2013), Király and Banai (2014)). Due to steeply rising nominal installments and stagnating net nominal wages, the share of defaulting borrowers significantly increased.

The present paper skips the details of these painful processes, rather it studies deterministic models of long-term mortgages, denominated either in domestic or foreign currency. We work out the equations of the repayment process; furthermore, analyze and display the repayment and debt paths on stylized data. Our starting point is the real cost of inflation, already discussed in the period of high inflation of the 1970s by Modigliani and Lessand (1975) and Fischer and Modigliani (1978) and applied to the analysis of a previous crisis of the Hungarian mortgage market by Simonovits (1992).

For expositional reasons, we shall illustrate our findings numerically. The initial debt is $10 \mathrm{~K}$ units, the repayment time is $T=20$ years. The total interest rate at home is $12 \%$, while abroad is $6 \%$. Deviating from the banks' practice, we calculate in years rather than months, but the difference is so small that it is negligible.

The structure of the remainder of the paper is as follows: Section 2 discusses the local currency (LC) loans based on annuity, emphasizing the impact of inflation with fixed real interest rate and perfect indexation (Fisher, 1930). Section 3 studies the FXD loans, with special emphasis on the uncovered interest parity, the depreciation shock and the change in the FX interest rate. We analyze LC and FXD loans' debt and repayment paths at nominal and real values. We also compare the financial position of the LC and the FXD borrowers. Section 4 models the optimal choice of the loan size in the two cases. Section 5 draws the conclusions.

\footnotetext{
${ }^{1}$ In extreme cases, the shocks were even stronger but we confine our attention to the average.

${ }^{2}$ Experts excluded such a solution earlier because lower incomes make the continuation of loans difficult.
} 


\section{Domestic annuity loans with inflation}

To better understand the problem of FXD loans, we start our analysis with domestic annuity loans with inflation. Let $D_{0}$ be the initial value of the loan, $T$ the maturity (payback time), and let $t=1,2, \ldots, T$ the index of repayment period (month, here year). Let $B_{t}$ be the installment paid at the end of period $t$, and let $R_{t}$ be the perperiod interest factor $(=1+$ interest rate $)$ and $D_{t}$ be the end-of-period debt. Then the following equation holds by definition:

$$
D_{t}=R_{t} D_{t-1}-B_{t}, \quad t=1,2, \ldots, T-1, T, \quad D_{0} \quad \text { given } .
$$

We shall need the compounded interest factor between the start of period 1 and the end of period $t$ :

$$
\mathbf{R}_{t}=R_{1} \cdots R_{t-1} R_{t}
$$

Using the concept of present value, the debt dynamics can be given by a closed formula as a function of the initial debt and the previous repayments:

$$
\mathbf{R}_{t}^{-1} D_{t}=D_{0}-\mathbf{R}_{1}^{-1} B_{1}-\mathbf{R}_{2}^{-1} B_{2}-\cdots-\mathbf{R}_{t-1}^{-1} B_{t-1}-\mathbf{R}_{t}^{-1} B_{t} .
$$

With rearrangement,

$$
D_{t}=\mathbf{R}_{t} D_{0}-\mathbf{R}_{t} \mathbf{R}_{1}^{-1} B_{1}-\mathbf{R}_{t} \mathbf{R}_{2}^{-1} B_{2}-\cdots-R_{t} B_{t-1}-B_{t} .
$$

At the end, the debt disappears, therefore (3) implies

$$
D_{0}=\mathbf{R}_{1}^{-1} B_{1}+\mathbf{R}_{2}^{-1} B_{2}+\cdots+\mathbf{R}_{T-1}^{-1} B_{T-1}+\mathbf{R}_{T}^{-1} B_{T} .
$$

In the case of long-term household loans, the bank typically prescribes a nominally unchanged installment $B .^{3}$ Then (5) yields

$$
D_{0}=\left[\mathbf{R}_{1}^{-1}+\mathbf{R}_{2}^{-1}+\cdots+\mathbf{R}_{T-1}^{-1}+\mathbf{R}_{T}^{-1}\right] B .
$$

In the simplest case, when the interest factor is time-invariant: $R_{t} \equiv R$, i.e. $\mathbf{R}_{t} \equiv R^{t}$, then using the formula for the sum of a geometric progression, (6) is simplified:

$$
D_{0}=\frac{R^{T}-1}{(R-1) R^{T}} B, \quad \text { i.e. } \quad B=\frac{R-1}{1-R^{-T}} D_{0} .
$$

In fact, due to the changes in the interest rate, the repayment path can be recalculated every period, pretending that no further changes occur.

\footnotetext{
${ }^{3}$ This condition only applies to household loans, and it has historic causes. We skip its detailed explanation.
} 
Theorem 1. If every period the creditor determines the annuity repayment as if the interest rate and future repayments remained fixed, then the repayment in period $t$ is equal to

$$
B_{t}=\frac{R_{t}-1}{1-R_{t}^{t-T-1}} D_{t-1}, \quad t=1, \ldots, T
$$

while the debt follows (1).

Figure 2 clearly displays that if the nominal value of the installments is constant, then at the start, it consists mainly of interest payment, and at the end, mainly of capital repayment, therefore the nominal value of the debt diminishes faster and faster.

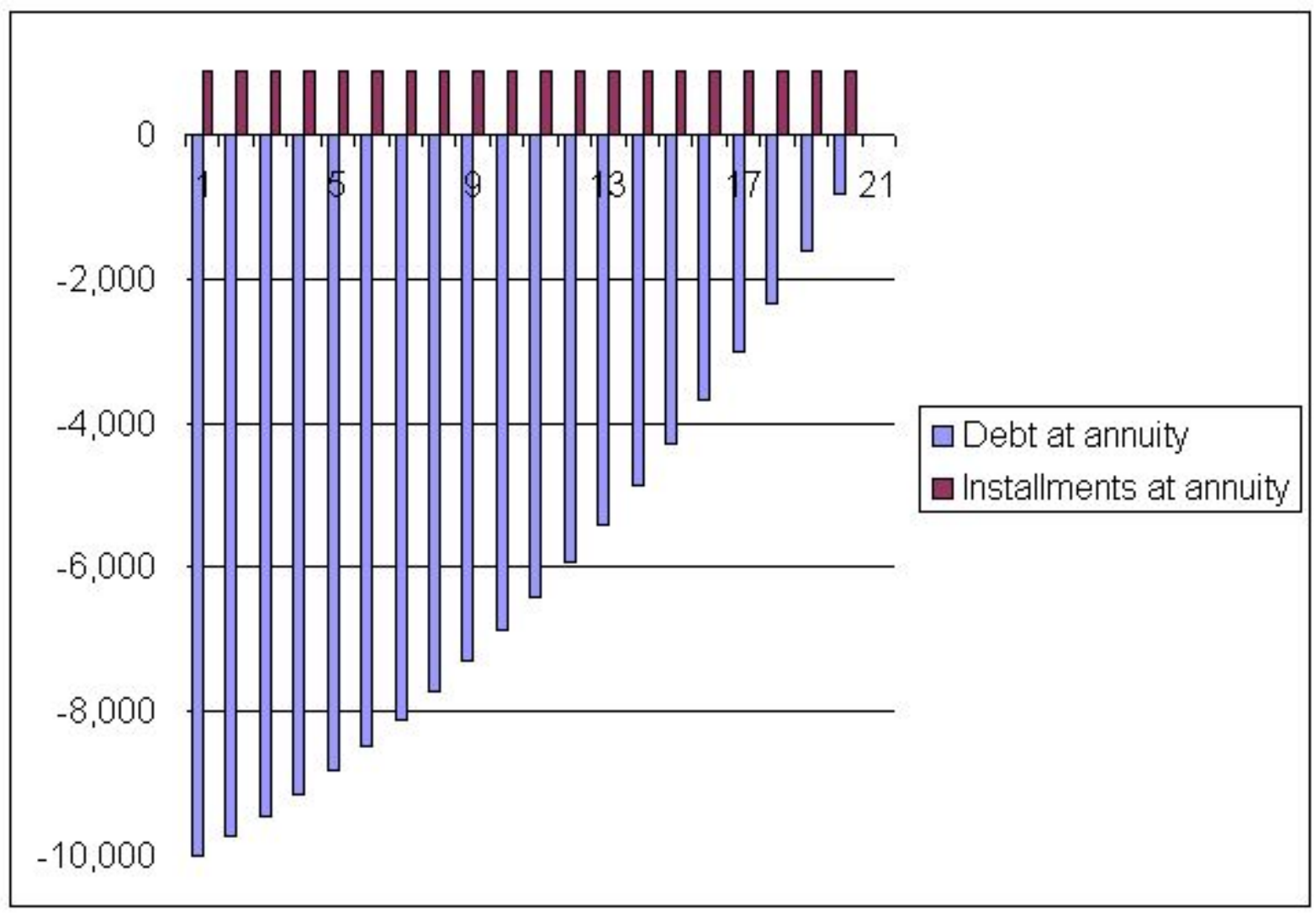

Figure 2. The repayment and debt paths with annuity. Mortgage size $=10000$ units, effective interest rate $=6 \%$, maturity $=20$ years,

To understand the nature of LC but especially of FXD loans, it is worth introducing the inflation and describe the problem in real terms. We shall use the 
inflation factor $p_{t}$ in period $t$ and the compounded inflation factor, the price index $P_{t}$ between periods 1 and $t, P_{t}=p_{t} P_{t-1}$ and $P_{0}=1$. With their help, we shall define the real interest factor, the real repayment and the real debt, respectively:

$$
r_{t}=\frac{R_{t}}{p_{t}}, \quad b_{t}=\frac{B_{t}}{P_{t}} \quad \text { and } \quad d_{t}=\frac{D_{t}}{P_{t}}
$$

We describe dynamics (1) in real terms:

$$
\frac{D_{t}}{P_{t}}=\frac{R_{t}}{p_{t}} \frac{D_{t-1}}{P_{t-1}}-\frac{B_{t}}{P_{t}}
$$

With the help of $(9),(10)$ reduces to

$$
d_{t}=r_{t} d_{t-1}-b_{t}, \quad t=1,2, \ldots, T, \quad d_{0} \quad \text { given } .
$$

Now we will examine the debt paths for various inflation rates. Let the real interest rate be $6 \%$, and assume perfect indexation, i.e. the nominal interest factor is equal to the product of the real interest factor and the inflation factor. This assumption can be interpreted as the ex post satisfaction of the well-known Fisherequation. Its usual simplification: nominal interest rate $\approx$ real interest rate + inflation rate.

Assuming different interest rates the resulting real repayment paths are quite different (Figure 3): for higher inflation, under perfect indexation the initial repayment is higher, but its real repayment faster decreases. In the inflation-free case, we just return to the path displayed in Figure 2.

The higher interest rate resulting from higher inflation raises the initial installment to an unaffordable level. For example, calculating with an annual inflation $10 \%$ and a 20-year maturity, the borrower should pay as much as $20 \%$ of the total loan in the first year. The majority of the borrowers do not understand that, due to the annuity formula, the initial repayment is mainly interest rather than capital service. This may prevent them to take up a loan, as happened before the introduction and the closure of the government sponsored domestic credit in Hungary, around 2004. For relatively small loans, this may be only an illusion but for relatively high loans, it is a real break. 


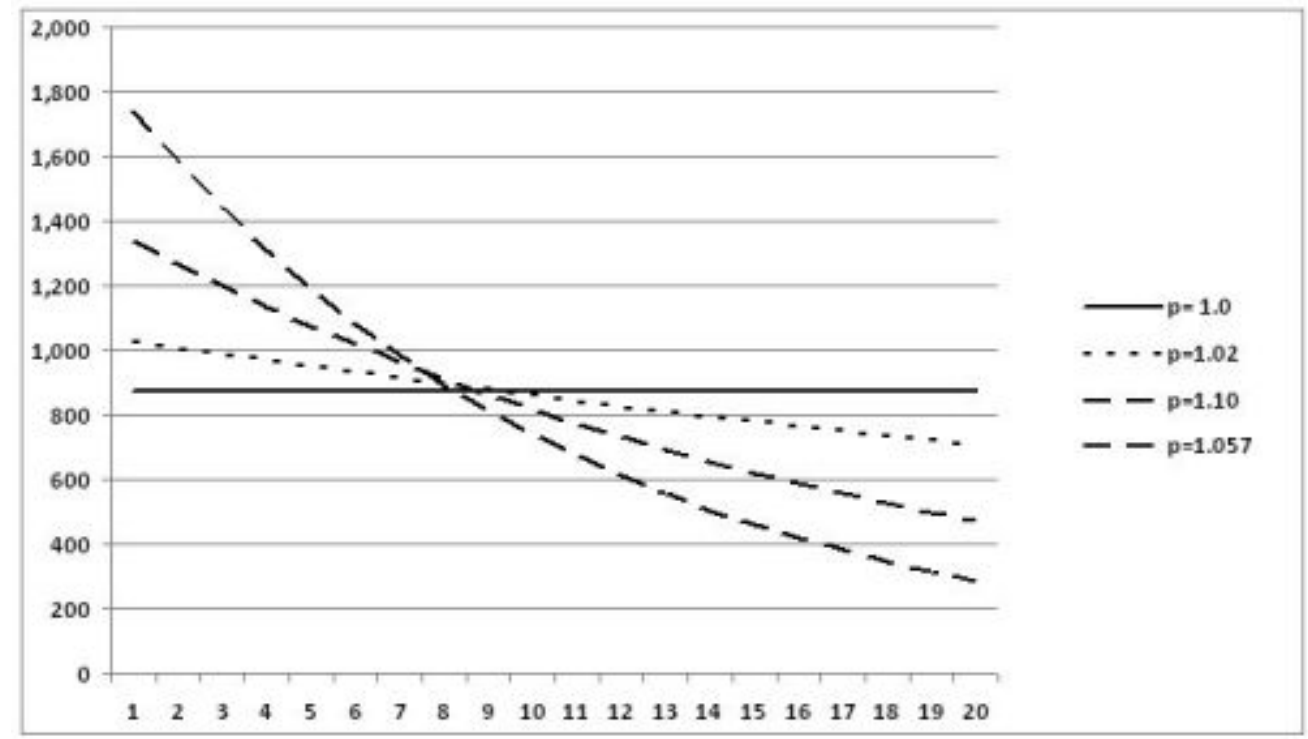

Figure 3. Real repayment paths for various inflation rates and fixed real interest rate $(r=1.06)$

\section{Foreign currency denominated loans}

Debt formed in foreign currency is a special form of dollarization. In most of the cases, the debtor's position is uncovered; her savings as well as her incomes come from domestic currency. Contrary to a widespread opinion, the FXD loan is not a substandard product, but it is neither riskless, therefore consumer protection measures should be taken (Heidhues, Kőszegi and Murooka (2012) analyze a similar case concerning the US credit cards).

The attractiveness of the FXD in the ECE countries had been increased by the expectation that until joining the Euro-zone, there will not be important changes either in the foreign interest rates or in the foreign exchange rates. In other words, the remaining period - presumed to be relatively short by many experts and debtorsthe uncovered parity will not hold. ${ }^{4}$ If the uncovered parity ex post holds, then the depreciation rate of domestic currency exactly expresses the difference between the domestic and foreign interest rates:

domestic interest factor $=$ foreign interest factor $\times$ depreciation factor or more familiarly but only approximately:

domestic interest rate $\approx$ foreign interest rate + depreciation rate.

\footnotetext{
${ }^{4}$ Of course, in the currency board countries (Baltic countries and Bulgaria) the depreciation was not a risk until the $\mathrm{CB}$ could be preserved.
} 
There are two reasons why the uncovered interest parity does not hold. ${ }^{5}$ The interest rate reflects the currency risk premium (due to the country risk, this was not negligible for Hungary) and there is a term premium (Schepp, 2008) between the interest rates for different maturities. In such cases, slower than uncovered interest parity depreciation or fixed exchange rate is conceivable, and just this happened in the foregoing countries in the period discussed. As a benchmark, in our analysis the debt and repayment process occurring at depreciation following interest parity will play a central role.

First we shall discuss the debt dynamics in foreign currency. Following the logic of the previous notations (and distinguishing the foreign currency's interest factor, debt and repayment by $\left.{ }^{*}\right)$, we have

$$
D_{t}^{*}=R_{t}^{*} D_{t-1}^{*}-B_{t}^{*}, \quad t=1,2, \ldots, T .
$$

Since the banks have to make the accounts of debt and repayment in domestic currency, and communicate with the borrowers in domestic units, we shall need the exchange rate $E_{t}$ and its relative change:

$$
e_{t}=E_{t} / E_{t-1}
$$

For simplicity, it is assumed that $E_{0}=1$, i.e. we only work with relative changes. Therefore converting the foreign accounts into domestic ones, the repayment and the outstanding debt are

$$
\tilde{B}_{t}=B_{t}^{*} E_{t}, \quad \text { and } \quad \tilde{D}_{t}=D_{t}^{*} E_{t} .
$$

Theorem 1 is now replaced by

Theorem 2. If every period the creditor determines the annuity repayment of FXD as if the foreign interest rate and future foreign currency repayments remained fixed, then the foreign currency repayment and its domestic counterpart in period $t$ are respectively equal to

$$
B_{t}^{*}=\frac{R_{t}^{*}-1}{1-R_{t}^{*(t-T-1)}} D_{t-1}^{*}
$$

and (14a), while the foreign and FXD debt follow (12) and (14b), respectively.

\footnotetext{
${ }^{5}$ The covered interest parity always holds, because the arbitrage pricing implies $f / s=(1+$ $i) /\left(1+i^{*}\right)$ holds, where $f$ is the forward exchange rate, $s$ is the spot exchange rate, $i$ and $i^{*}$ are the domestic and foreign interest rates. The uncovered interest parity states the same for the expected exchange rate: $s^{*} / s=(1+i) /\left(1+i^{*}\right)$, but is may not hold ex post for a number of reasons.
} 
(14a) attests that the FXD loans' installments are proportional to the exchange rate $E_{t}$. If there is no depreciation, then the converted installments are also fixed, and the path perfectly coincides with the base run.

We shall transform the formula for the foreign currency debt dynamics. Multiplying both sides of (12) by $E_{t}=e_{t} E_{t-1}$,

$$
D_{t}^{*} E_{t}=R_{t}^{*} e_{t} D_{t-1}^{*} E_{t-1}-B_{t}^{*} E_{t}, \quad t=1,2, \ldots, T .
$$

We shall need the notion of imputed domestic interest factor, equaling to the product of the foreign currency interest factor and of the depreciation factor: $\tilde{R}_{t}=$ $R_{t}^{*} e_{t}$.

Then the FXD loan's debt dynamics conform to that of the domestic [(1)] or of the foreign exchange [(12)]:

$$
\tilde{D}_{t}=\tilde{R}_{t} \tilde{D}_{t-1}-\tilde{B}_{t}, \quad t=1,2, \ldots, T,
$$

only $R_{t}$ and $R_{t}^{*}$ are replaced by $\tilde{R}_{t}$ in the corresponding debt equations. Though no bank calculates with such a formula or interest factor, its use helps in the comparison of the two types of loans.

If the actual and the imputed interest factors are equal: $R_{t}=\tilde{R}_{t}=R_{t}^{*} e_{t}$, then the burden of the two loans are the same, except for the repayments are varying in time. Since this path is quite special, we shall consider it as a benchmark path. This is exactly the case of uncovered interest parity (domestic interest factor $=$ foreign interest factor $\times$ depreciation factor). If $R_{t}>\tilde{R}_{t}$ holds along the repayment period (to be called super-parity), then the domestic loan is more costly than its FXD counterpart; if, on the other hand, $R_{t}<\tilde{R}_{t}$ holds along the repayment period (to be called sub-parity), then the domestic loan is less costly than its FXD counterpart. We shall examine the mixed case later on.

We turn now to the study of nominal and real paths of repayment and debt of a FXD mortgage in relation to a domestic mortgage with the same loan size and maturity. We shall start with the nominal repayment path of FXD mortgages under various depreciation rates (neglecting domestic inflation). As was already justified in Section 2, we calculate with a domestic nominal interest rate $12 \%$, the foreign counterpart is $6 \%$, the payback time remains 20 years and the loan size remains 10 $\mathrm{K}$ units. The uncovered interest parity corresponds now to an annual depreciation rate $100 \times(1.12 / 1.06-1)=5.66 \%$. We investigate the nominal paths in Figure 4 for four different depreciation rates: one corresponding to parity, another with faster deprecation and the third one with a slower one and finally, with no deprecation. 


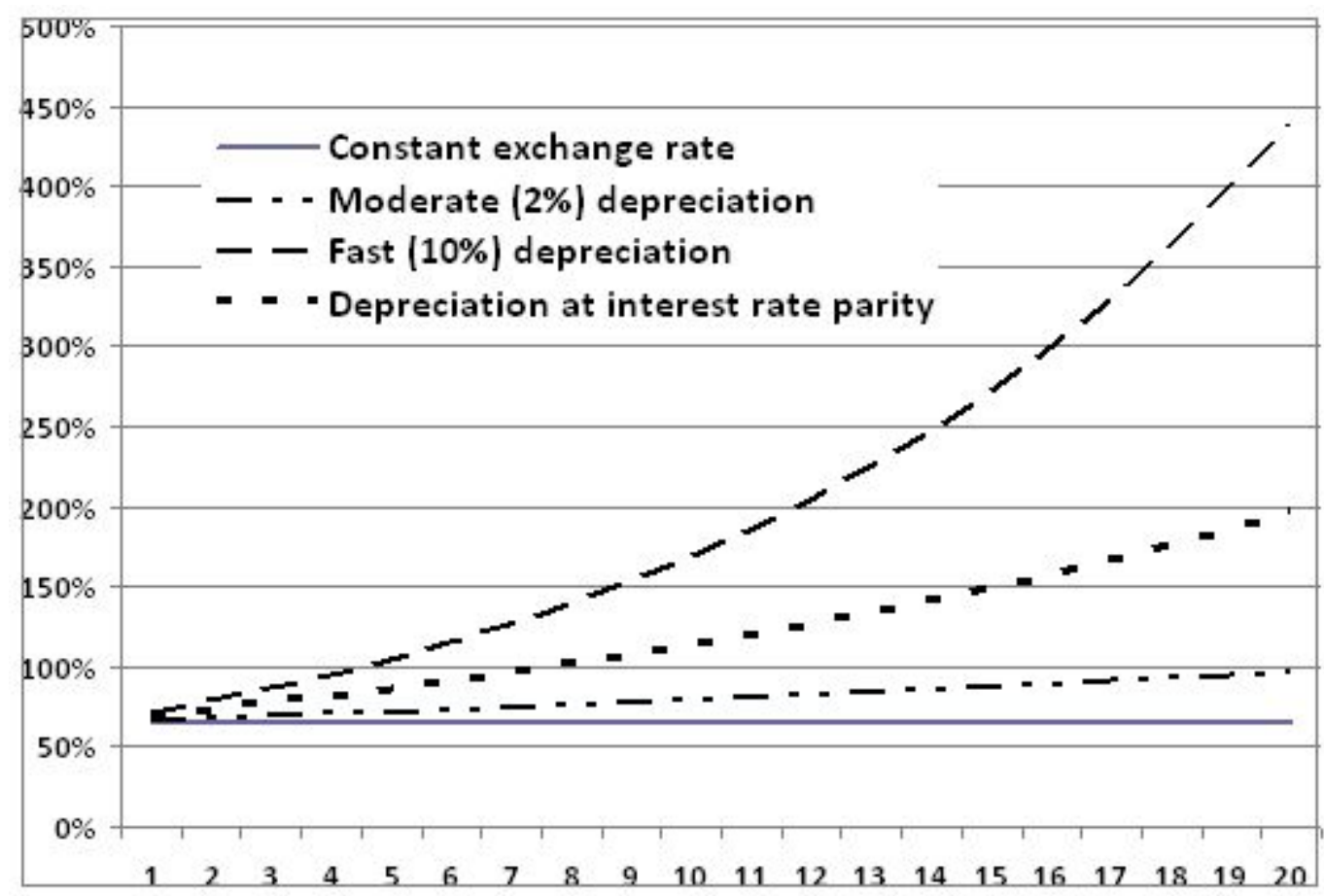

Figure 4. The repayment paths of FXD loans in LC, relative to the LC counterpart, various depreciation rates

Figure 4 clearly shows the impact of depreciation on the borrower's burden: the FXD loan's installment starts below from that of the LC counterpart, but quickly surpasses it. For very low depreciation, the FXD installments remain below the domestic one, but even then it rises by $50 \%$. If the annual depreciation corresponds to the uncovered interest parity, then the FXD installment already surpasses the LC-based one in year 8! If the debtor took up a loan which she would have been able to repay only for fixed exchange rate, than she would experience liquidity crisis, due to the elevated installments. If in addition, she adjusted the loan size to the initial domestic installments, and took up a mortgage which she would not been able to repay in the domestic construction, then she would encounter financial difficulties even for minor depreciation.

It is evident that if the domestic inflation rate is lower than the depreciation rate, then the real value of the FXD repayment also increases; if the two rates are equal, then the real value of the repayment is constant, and only if the domestic inflation rate is higher than the depreciation rate, then the real value of the repayment decreases. Therefore in real terms, in comparison to the monotonously decreasing real installments, the FXD loan's installments are only more favorable if the interest rate is much higher than the depreciation rate. Since the FXD loans were typically wide spread in those countries where the inflation was fast and volatile, therefore 
the nominal interest rates were high with respect to other, low-inflation countries (like Switzerland). For low inflation (like in the Czech Republic), the interest rate difference - generating the FXD loans - probably does not exist at all. Starting an FXD loan, the debtor projected a similar situation, and calculated a declining real repayment path, similar to those of the domestic loan's. In contrast, ex post she encountered a significant domestic depreciation and disinflation.

Until now we examined the debtors' repayment paths. Now we turn to their debt paths (Figure 5).

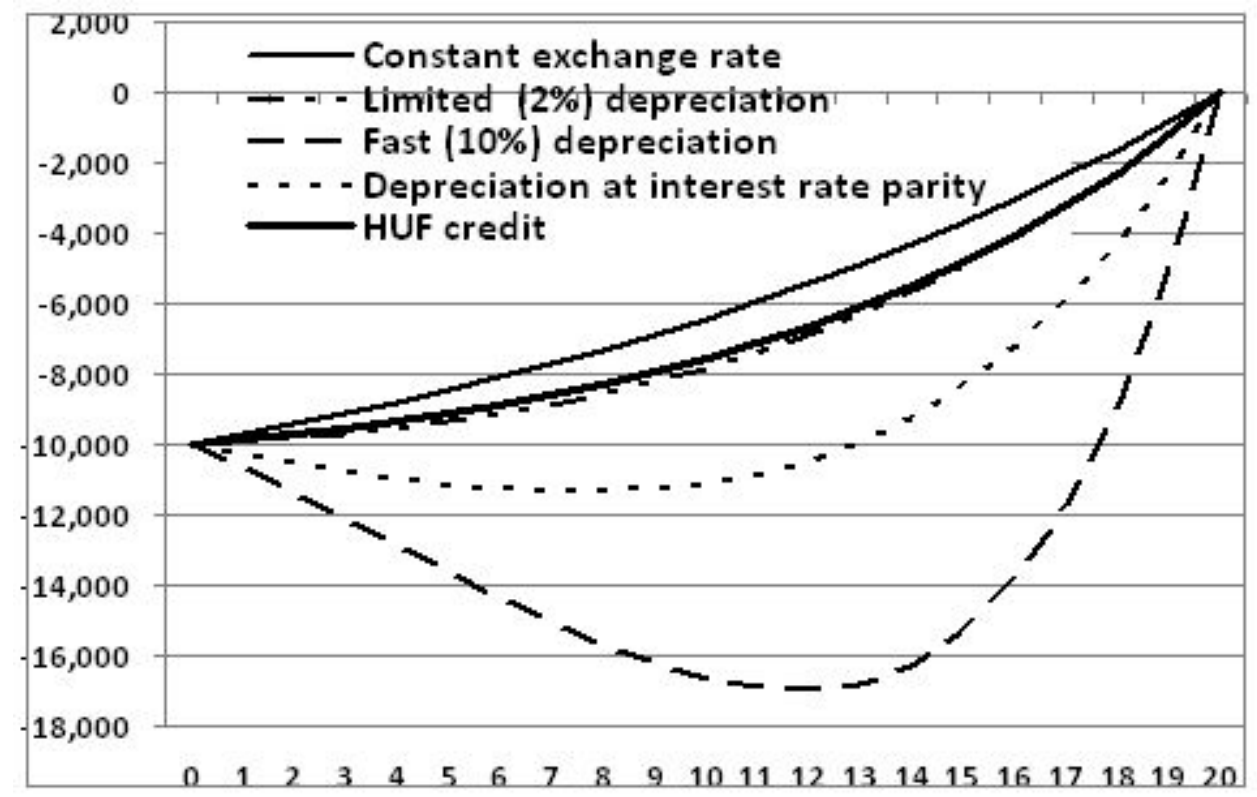

Figure 5. The nominal debt path of LC and FX denominated mortgages, various depreciation rates.

Figure 5 attests that for slow annual depreciation, the two debt paths almost coincide, but for significant depreciation, for a long enough initial period, the FXD debtor experiences a higher nominal debt than at the start. We call attention to the bulge appearing at the annual depreciation of $10 \%$.

These results apparently suggest that the FXD debtors are worse off than the domestic debtors, both having the same loan size: rising nominal installments, deepening debt paths, and even in real terms their debt may increase for a while. If we look behind the appearances, and compare the welfare of the two groups as economists should do, then we must remember that the FXD debtors started with a much lower installment. They could have consumed or saved the difference, which meant a welfare advantage. Among the various possibilities, one of the simplest possibilities is to compare the present values of the two repayment paths, using an appropriate discount factor. 
For constant interest rates, the present values of the two repayment streams are as follows:

$$
\mathrm{PV}=\sum_{t=1}^{T} R^{-t} B_{t} \quad \text { and } \quad \widetilde{P V}=\sum_{t=1}^{T} R^{-t} \tilde{B}_{t}
$$

For time-varying interest rates, we must return to the compounded interest factors introduced in Section 2:

$$
\mathrm{PV}=\sum_{t=1}^{T} \mathbf{R}_{t}^{-1} B_{t} \quad \text { and } \quad \widetilde{\mathrm{PV}}=\sum_{t=1}^{T} \mathbf{R}_{t}^{-1} \tilde{B}_{t} .
$$

Note that due to normalization $E_{0}=1$, discounting FXD loans by the corresponding foreign interest rates returns the original loan:

$$
\mathrm{PV}^{*}=\sum_{t=1}^{T} \mathbf{R}_{t}^{*-1} B_{t}^{*}=\mathrm{PV} .
$$

The lower the present value, the lower is the repayment burden. We are not interested in the triviality that the loan size is equal to the present value of the repayment, using the corresponding interest rate at discounting. Therefore if we discounted the FXD repayment stream by the virtual discount factor $\tilde{\mathbf{R}}_{t}$, we could obtain

$$
\widetilde{\mathrm{PV}^{*}}=\sum_{t=1}^{T}\left(E_{t} \mathbf{R}_{t}\right)^{-1} \tilde{B}_{t}
$$

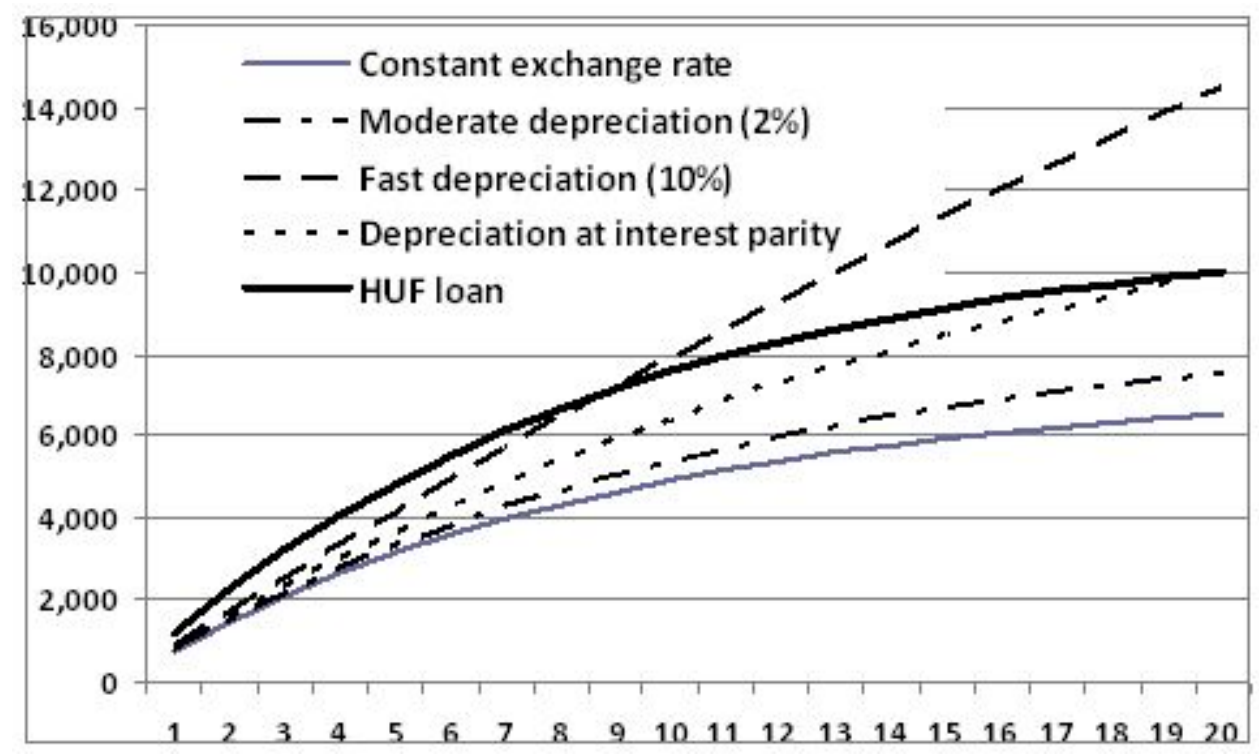

Figure 6. The censored present values of LC and FX denominated mortgages, from the start to the varying end (using the $\mathrm{LC}$ interest rate $12 \%$ at discounting). 
We use this tool to compare two repayment streams: one in LC, the other in FXD. To make a meaningful comparison, we use the domestic interest rate at the common discounting. Note that this practice overvalues the initial welfare advantage of the FXD debtors over the domestic debtors'.

Figure 6 displays the censored present values of the two types of loans, they are calculated for various end-points of the repayment period. Therefore the realized burdens are comparable for any end-points. For example, the values at the end of year 6 show the present values of the realized repayments: 6,100 units for a LC loan of 10,000 units, with maturity 20 years. The corresponding numbers vary with varying depreciation rates, all lower than the LC counterpart. For example, even with the dramatic annual depreciation rate $10 \%$ only yields 5,682 units. But looking at 18 years, the ranking is reversed, at least for this extreme case: 9,706 units vs. 13,282 units.

It is not surprising that for a constant exchange rate, the FXD debtor has the same PV-gain over the LC debtor during the total repayment period. For slow depreciation, the initial PV-advantage of the FXD debtor uniformly decreases. When the depreciation rate exactly matches the interest rate differences, the FXD debtor's advantage disappears at the end. Finally, if the depreciation is even faster than the interest rate parity would require, then the initial PV-advantage sooner or later turns into a PV-loss. We recall again that the majority of the FXD debtors had chosen a higher loan than the LC debtors (see its analysis in Section 4 below), therefore they were unable to make profit of their temporary advantages. Looking back from the end of 2014, we see the FXD borrowers at their years 6-10 of their borrowing, therefore according to our Figure 6, they still enjoy their PV-advantages over their LC counterparts.

Until now we have assumed that the depreciation rate is time-invariant. Now we model the impact of the exchange rate shocks which occurred in several ECE countries between 2008 and 2011. The FXD debtors, starting their repayment process several years before the crisis, enjoyed a sub-parity depreciation or even appreciation during the first part of their (shorter or longer) repayment periods, ending in 2008. But since the depreciation shocks of 2008, 2010 and 2011, the majority of these cohorts suffered from super-parity (defined above). The only exception is the cohort of the earliest entrants, who took up their FXD loans in 2004 and 2005, and their present values lie below the parity path.

For the sake of simplicity, in Figure 7, we only consider five cohorts, different from each other by their dates of taking up the FXD loan: $\tau=0,-1,-2,-3,-4$, i.e. we assume that the crisis started in year 0. Imitating the reality, we assume that in year 0 the $\mathrm{FX} / \mathrm{LC}$ depreciation was equal to $25 \%$ and in year 2 to another $25 \%$, altogether $56 \%$. Therefore the installments rose by $25 \%$ in year 0 and $56 \%$ in 
year 2 and then remained stable. ${ }^{6}$ Using our earlier methodology we determine the present value of the realized repayments for every year of the repayment period, and then compare them with the counterpart of the LC borrowers.

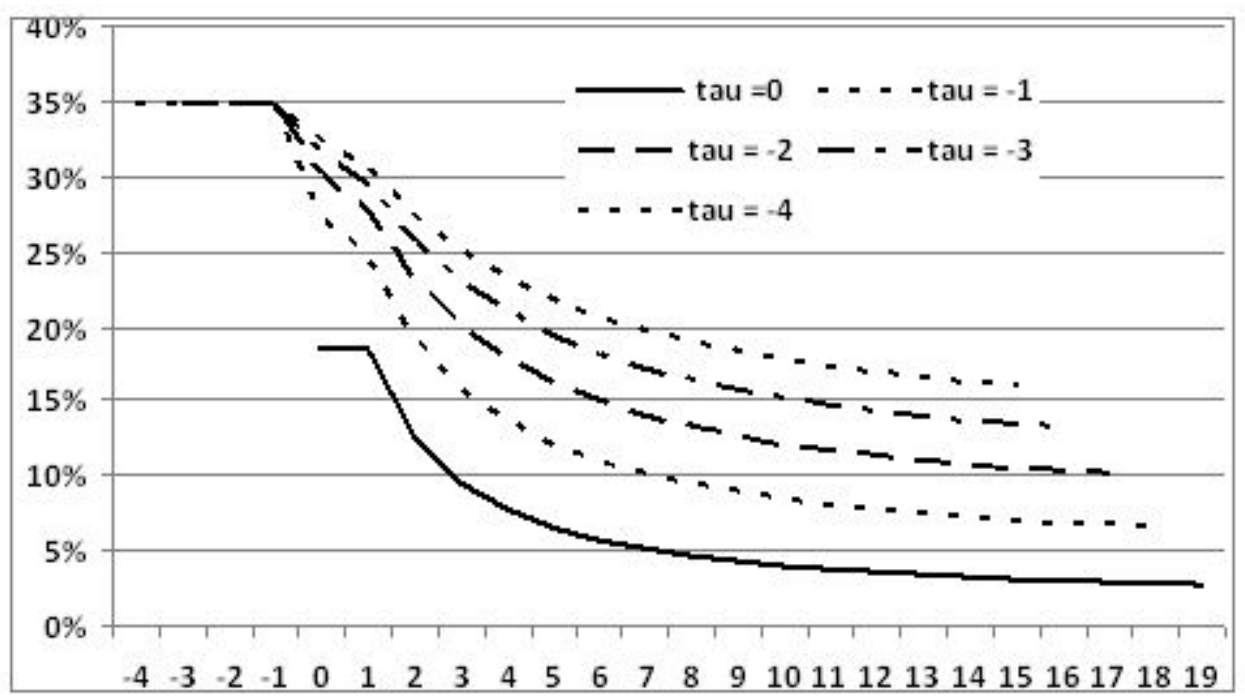

Figure 7. The relative PV advantage of the FXD debtors over the LC debtors, depending on the start, at depreciation shocks, using the discount factor $12 \%$.

Until now we have neglected a very important dimension of the Hungarian FXD mortgage history, namely from the banks' one-sided raise of the interest rate. We have already mentioned that during the risk shock, when the banks' cost dramatically jumped, the banks raised the effective interest rates of their FXD mortgages. If we also model this interest rate shock, assuming that the interest rate rose by $1-1$ percent point in year 0 and 1 , then the picture significantly changes: only the PV advantages of early borrowers $(\tau=-3$ and -4$)$ remain, the others $(\tau=-0,-1$ or -2 ) lose out, their curves enter the negative domain. In other words: those, who took up their FXD loans much before the crisis arrived, gained; all the others lost (Figure 8). This is consistent with other expert calculations. ${ }^{7}$

\footnotetext{
${ }^{6}$ This assumption is only a stylized counterpart of the reality and neglects the further depreciation but this is immaterial from our point of view.

${ }^{7}$ Cf. De Facto blog, Index.hu, February 26, 2014. http://index.hu/gazdasag/defacto/2014/02/24/itt_az_igazsag_a_devizahitelekrol/.
} 


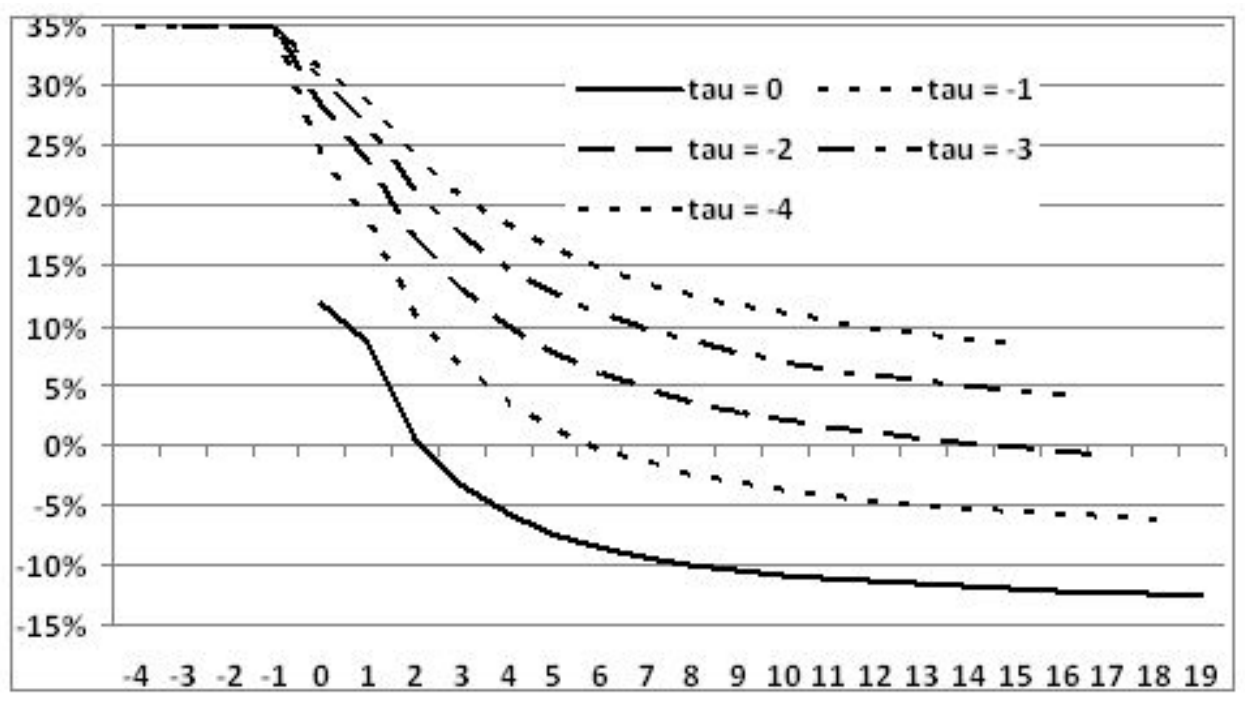

Figure 8. The relative PV advantage of the FXD debtors over the LC debtors, depending on the start, at depreciation shocks and interest rate shock, using the discount factor $12 \%$.

In contrast to the depreciation, the impact of a rise of interest rate is nonlinear, therefore we shall determine the trade-off between them. For a fixed LC interest rate, the $\mathrm{LC} \mathrm{PV}$ of a FXD mortgage is

$$
\widetilde{\mathrm{PV}}=\sum_{t=1}^{T} R^{-t} \frac{\left(R^{*}-1\right) D_{0}}{1-R^{*-T}} E_{t} .
$$

Inserting (15) into our last equation yields

$$
E\left(R^{*}\right)=\frac{R_{0}^{*}-1}{1-R_{0}^{*-T}} \frac{1-R^{*-T}}{R^{*}-1},
$$

Fixing the domestic interest factor $R_{0}$ and $\widetilde{\mathrm{PV}}$, we obtain the trade-off function $E\left(R^{*}\right)$.

Calculating with the base values $T=20$ years and $R^{*}=1.06$, the following trade-off is obtained: if the FX interest rate rises from 6 to $7 \%$, then the neutral depreciation level is $7.6 \%$; if the FX interest rate rises from 6 to $8 \%$, then the neutral depreciation level is equal to $14.4 \%$. In the opposite direction, a rise in the FX interest rate from 6 to $7 \%$ was equivalent to a LC weakening of $8.2 \%$, while a rise in the $\mathrm{FX}$ interest rate from 6 to $8 \%$ was equivalent to a $\mathrm{LC}$ weakening of $16.8 \%$. As a result, the nominal LC repayment rose not only by $56 \%$ (due to depreciation) but also by $16.8 \%$ (due to the rise in the FX interest rate). 


\section{Optimal loan size}

Until now we considered the size of the mortgage as given and compared the welfare of various debtors for this given value. In this Section we make a trial to determine the optimal loan size for a given real wage path, neglecting financial savings. Using Samuelson (1937) additive discounted life-time utility function, (being the simplest concave utility function), but we attribute utility not only to the annual consumption but to the use of dwelling.

Let us denote the nominal wage by $W_{t}$, installment by $B_{t}$ and the consumption by $C_{t}$ in year $t$. Turning to real variables,

$$
w_{t}=\frac{W_{t}}{P_{t}}, \quad b_{t}=\frac{B_{t}}{P_{t}} \quad \text { and } \quad c_{t}=\frac{C_{t}}{P_{t}} .
$$

Assuming time-invariant interest rates (i.e. dropping their time index), the real consumption (cf. (7)) is determined by

$$
c_{t}=w_{t}-b_{t}, \quad b_{t}=\beta_{t} D_{0}, \quad \beta_{t}=\frac{R-1}{\left(1-R^{-T}\right) P_{t}},
$$

where $\beta_{t}$ is the corresponding repayment rate.

We choose the simplest lifetime utility function: we optimize the usual logarithmic utility function of consumption for the repayment period and the logarithmic utility of the dwelling for an infinite period. We dropped the logarithmic utilities of consumption for the post-repayment period, since those are independent of the chosen loan size. ${ }^{8}$ Let $\kappa$ be the relative utility of the dwelling per year. Assuming that the dwelling is purely financed from mortgage, i.e. LTV $=100 \%^{9}$, the lifetime utility function is equal to

$$
U\left(c_{1}, \ldots, c_{T}, D_{0}\right)=\sum_{t=1}^{T} \delta^{t} \log c_{t}+\kappa \sum_{t=1}^{\infty} \delta^{t} \log D_{0}=\sum_{t=1}^{T} \delta^{t} \log c_{t}+\kappa \Delta \log D_{0},
$$

where $\delta$ is the annual discount factor and

$$
\Delta=\frac{\delta}{1-\delta}
$$

is the summarized discount factor. Then the optimal loan size can be determined.

\footnotetext{
${ }^{8}$ In more realistic models one should take into account those expenditures which depend on the size of the dwelling.

${ }^{9}$ In our simple optimization model, the LTV does not play any important role. For example, if the loan is only $\alpha$ times the dwelling value, then due to $\log \left(\alpha D_{0}\right)=\log \alpha+\log D_{0}$, $\alpha$ is immaterial.
} 
Theorem 3. The optimal domestically denominated loan size $D_{0}^{\circ}$ is uniquely determined from the following implicit equation:

$$
0=\sum_{t=1}^{T} \frac{-\delta^{t} \beta_{t}}{w_{t}-\beta_{t} D_{0}}+\frac{\kappa \Delta}{D_{0}} .
$$

Remark. Removing the denominators, we obtain a polynomial equation of degree $T+1$, which has $T+1$ roots. Due to having a monotone right hand side, (21) has a unique positive root but it cannot be determined explicitly except for special cases. We shall use a numerical method for its determination.

Proof. Inserting the consumption path (18) into the utility function (19) take the derivative of $U\left[D_{0}\right]$ and make it zero. This yields the first-order condition (21) which is necessary and sufficient.

There is a case when an explicit formula determines the optimal loan size; if the real wages are time-invariant: $w_{t}=w$ and there is no inflation: $P_{t}=1, R>1$. Then the real repayment rate is

$$
\beta_{t}=\frac{R-1}{1-R^{-T}}
$$

and (21) simplifies to

$$
\frac{\delta\left(1-\delta^{T}\right) \beta}{\left(w-\beta D_{0}\right)(1-\delta)}=\frac{\kappa}{D_{0}(1-\delta)} .
$$

After rearrangement, the optimal loan size is given as

$$
D_{0}^{\mathrm{o}}=\frac{\kappa w\left(1-R^{-T}\right)}{\left(1-\delta^{T}+\kappa\right)(R-1)} .
$$

Hence the optimal loan size

- is proportional to the real income; from a higher income one can finance proportionally higher loan and larger dwelling;

- is proportional to the relative utility of the dwelling; the more important the dwelling for us relative to other goods, we buy a larger dwelling (and take up a larger mortgage) at the cost of reducing the consumption of other goods;

- and is approximately inversely proportional to the interest rate; the more expensive the credit, the smaller dwelling is available and we choose a smaller mortgage.

In an inflationary environment, we again suppose that the indexation is perfect, the Fisher equation is valid, i.e. the nominal interest rate changes parallel with the inflation rate. Now the real repayment rate $\left(\beta_{t}\right)$ ceases to be time-invariant, there is no closed formula for the optimal mortgage size. At the same time, it can be 
proved that the inflationary higher interest rate raises the real repayment rate more than the price rise diminishes it, i.e. the optimal size is a decreasing function of the inflation rate.

The optimal FXD mortgage size $\left(D_{0}^{\circ}\right)$ can be determined similarly to $(24)$; only the real repayment rate contains the foreign currency interest rate and need be corrected by the depreciation level $\left(E_{t}\right)$.

There is no simple answer whether the LC or the FXD loan-size is higher in the optimal case. The answer depends on the parameter values of the interest rates, the depreciation rate and the inflation rate. Of course, if there is neither inflation, nor depreciation, but nominal interest rate $=$ real interest rate $=$ foreign currency interest rate, then the two real repayment rates are the same; therefore the two optima are also the same. For more general assumptions, only weaker answer can be given, depending on the parameter values.

Let us assume that both the Fisher-equation $(R=r p)$ and the uncovered interest parity $\left(R=R^{*} e\right)$ hold ex post, i.e. the domestic real interest factor $=$ foreign currency interest factor $\left(r=R^{*}\right)$, and let us have a positive inflation rate. Our intuition suggests that there cannot be any difference between the two optima: what the FXD borrower gains from the lower initial repayment, he loses on the depreciation. Translating into the real repayment rates: the LC borrower has a declining repayment rate, while the FXD borrower has a time-invariant one, and the two repayment paths meet sometime. At the beginning, the FXD borrower is better-off, at the end, the LC borrower. We can give the optimal FXD loan size, because under our two assumptions, the FXD repayment rate is time-invariant:

$$
\tilde{\beta}=\frac{R^{*}-1}{1-R^{*-T}} ;
$$

and the optimal loan size is given by

$$
\tilde{D}_{0}^{\mathrm{o}}=\frac{\kappa w\left(1-R^{*-T}\right)}{\left(1-\delta^{T}+\kappa\right)\left(R^{*}-1\right)} .
$$

As was already mentioned, we shall determine the optimal LC loan size numerically. Repeating our earlier statement, the ranking will depend on the chosen parameter values. If the real $\mathrm{LC}$ interest rate is sufficiently low and there is inflation, then the FXD optimum is greater than its LC counterpart. For high LC real interest rate and low inflation rate, the reverse is true.

Consider the following plausible parameter value set: $\kappa=1 / 3, w=3,000$ units and $T=20$ years ${ }^{10}$, and fix the inflation rate at the foregoing country's National

\footnotetext{
${ }^{10} \mathrm{An}$ annual discount factor of 0.95 is plausible for our logarithmic utility functions, $w=3,000$ units is the minimum, it could be relaxed by a rising wage-age schedule. The choice $\kappa=1 / 3$ yields reasonable loan sizes.
} 
Bank's target: $p-1=0.03$, then Figure 9 shows that for rising real (FX) interest rate at first the FXD optimum, then the LC optimum is greater than the other.

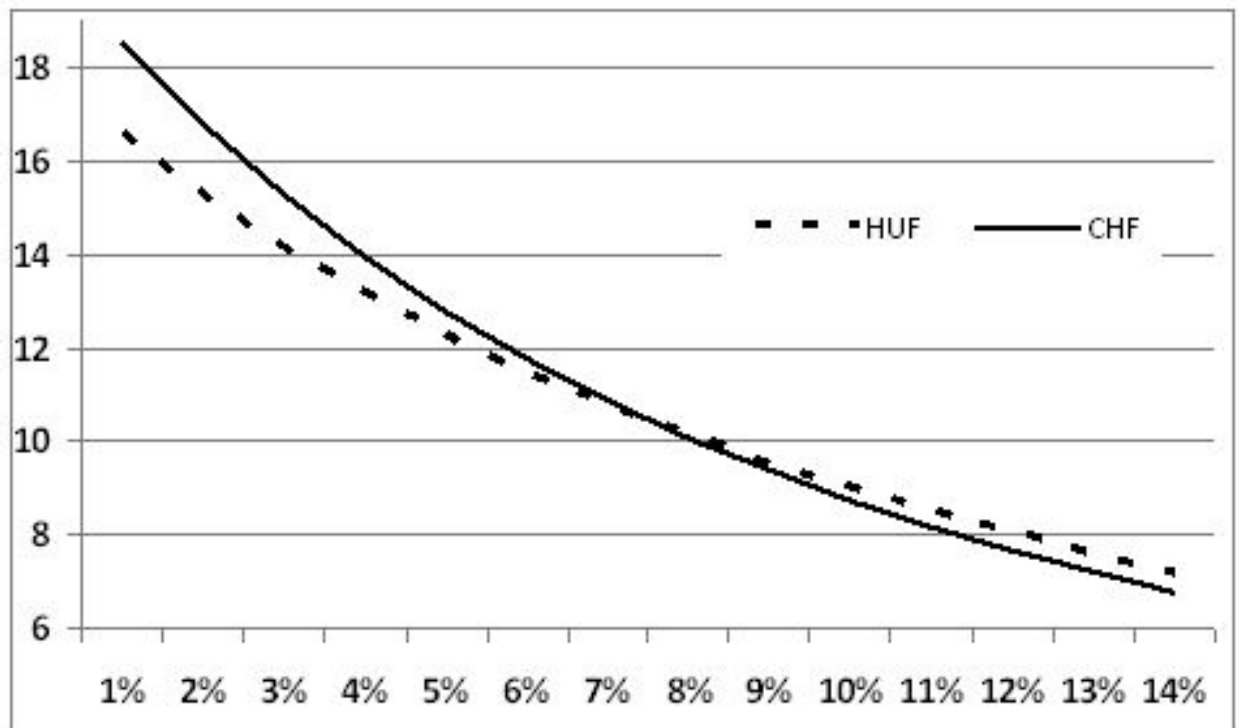

Figure 9. The optimal loan size in LC and FX denominated loans.

Illustrating ours findings by the Hungarian case: between 2004 and 2008 the FXD borrowers encountered FX interest rates of 4-7\% (on average, 6\%) and inflation rates of $4-8 \%$ (on average, $6 \%$ ), while the LC interest rate was $10-13 \%$ (on average, $12 \%)$. In such an environment, our oversimplified model gave a slightly higher (3$5 \%$ ) optimal loan size for the FXD than the LC mortgage.

\section{Conclusions}

The present study applied very simple models for discovering several properties of the FXD loans. Our first result shows those inflationary and exchange rate paths for which the financial burden of the domestic and FXD loans are the same. To do so we introduced the mixed present value of the FXD loans discounted by the domestic interest rate. We demonstrated the benchmark role of the exchange rate path satisfying the uncovered interest parity, where the two types of debtors have the same burden. Analyzing actual exchange rate paths, we showed that the relative situation of the FXD debtors would have been much better than the domestic debtors without the one-sided interest rate rises. Further research may compare internationally the two types debtors' financial situation.

We were able to obtain a simple formula for the trade-off between a one-time depreciation and a permanent interest rate rise. Under the circumstances of the 
Hungarian FXD loans, 1 percent point rise in the FX interest rate is equivalent to a once-and-for-all depreciation of 8-9\%. This provides an answer to the deterioration of the FXD debtors: their drop in welfare arises from the simultaneous shock of exchange rate and interest rate. This may serve as a starting point for further research in the issue of nonperforming loans.

Introducing the real values of the repayments is especially important because of their use in the consumption model. In this framework, we have constructed a very simple model for calculating the optimal loan size. It only yields very primitive results; for example, the numerical conditions when the FXD mortgage results in a larger loan-size than the domestic one. Using calibrated data, the former is greater than the latter. The comparison of our results with the actual behavior was beyond the scope of our research but developing the model it could be used to examine further fields discussed in the literature, namely excessive indebtedness, non performance etc.

\section{References}

Bethlendi, A. (2011): "Policy Measures and Failures on Foreign Currency Household Lending in Central and Eastern Europe", Acta Oeconomica 61, 193-223.

Brown, M., and De Haas, R., (2012): "Foreign Banks and Foreign Currency Lending in Emerging Europe", Economic Policy 69, 57-98.

Fidrmuc, J., Hake, M. and Stix, H. (2013): "Households' Foreign Currency Borrowing in Central and Eastern Europe", Journal of Banking \&5 Finance 37(6), 1880-1897.

Fischer, S. and Modigliani, F. (1978): "Towards an Understanding of the Real Effects and Costs of Inflation", Weltwirtschaftlisches Archiv 114, 810-833.

Fisher, I. (1977) (1930). The Theory of Interest. Philadelphia: Porcupine Press.

Heidhues, P., Köszegi, B. and Murooka, T. (2012): "Deception and Consumer Protection in Competitive Markets", The Anthology on Pros and Cons of Consumer Protection, 44-76.

Király, J. and Banai, A. (2014): "Foreign Currency Lending: The 'Flow' and the 'Stock' problem. National Bank of The Republic of Macedonia: 2nd Research Conference Policy Nexus and the Global Environment: A New Consensus Emerging from the Crisis?, NBRM, Skopje.

Modigliani, F. and Lessand, D. (1975): "New Mortgage Designs for Stable Housing in Inflationary Environment", Federal Reserve Bank of Boston, Conference Series, 14, Boston MA.

Pitz, M. and Schepp, Z. (2013): "An Examination of Pricing Bank Loans by Structural VAR Model", Hungarian Review of Finance 58, (in Hungarian) 434-447. 
Samuelson, P. A. (1937): "A Note on Measurement", Review of Economic Studies 4, 156-161.

Simonovits, A. (1992): "The Mathematics of the Hungarian Mortgage Reform in 1991", Eastern European Economics 30, 121-133.

Schepp, Z. (2008): "Reflections on the Risk of Foreign Currency Loans Financed with Variable Interest Rate", Hungarian Credit Review 7, (in Hungarian) 67-90.

Zettelmeyer, J., Nagy, P. M. and Stephen, J. (2010): "Addressing Private Sector Currency Mismatches in Emerging Europe", EBRD WP 115 (June). 